\title{
Selective inhibition of fatty acid oxidation in colonocytes by ibuprofen: a cause of colitis?
}

\author{
W E W Roediger, S Millard
}

\begin{abstract}
Ibuprofen is associated with initiation or exacerbation of ulcerative colitis. As ibuprofen selectively inhibited fatty acid oxidation in the liver or caused mitochondrial damage in intestinal cells, its effect on substrate oxidation by isolated colonocytes of man and rat was examined. Ibuprofen dose dependently $(2 \cdot 0-7 \cdot 5$ mmol/1) and selectively inhibited ${ }^{14} \mathrm{CO}_{2}$ production from labelled n-butyrate in colonocytes from the proximal and distal human colon $(n=12, p=<0 \cdot 001)$. Glucose oxidation was either unaltered or increased. Because short chain fatty acid oxidation is the main source of acetyl-CoA for long chain fatty acid synthesis, the inhibition of prostaglandin synthesis by ibuprofen in the colonic mucosa could also occur at this level. Because the concentrations of ibuprofen that can be attained in the human colon are not known, conclusions drawn from current dosages are tentative. The inhibition of fatty acid oxidation by ibuprofen may be biochemically implicated in the initiation and exacerbation of ulcerative colitis, manifestation of which would depend on the ibuprofen concentrations reached in the colon.

(Gut 1995; 36: 55-59)
\end{abstract}

Keywords: ibuprofen, colitis, colonocytes, fatty acid oxidation.

Non steroidal anti-inflammatory drugs (NSAIDs) can have deleterious effects on the intestinal mucosa. In the colon, these drugs can produce colitis de novo or cause exacerbation of quiescent ulcerative colitis. ${ }^{1-3}$ NSAIDs produce permeability changes in the colonic mucosa independent of colitis, ${ }^{4}$ or cause colonic bleeding ${ }^{5}$ with or without stricturing and diaphragm formation. ${ }^{67}$ Even though the inhibition of cyclo-oxygenases and therefore prostaglandin production has been invoked as a causative factor of damage, ${ }^{13}$ there also seems a lack of correlation between reduced mucosal synthesis of prostaglandins and the degree of mucosal injury. ${ }^{8}$

The epithelial barrier of the colonic mucosa in health is maintained by nutrition from the lumen through $n$-butyrate ${ }^{9-11}$ derived from bacterial fermentation of starches. Fatty acid oxidation of n-butyrate in colonocytes governs the supply of acetyl-CoA for oxidative and synthetic functions of epithelial cells, such as lipogenesis, ${ }^{12}$ mucus synthesis, and processes of detoxification. ${ }^{13}$ Inhibition of n-butyrate oxidation is associated with formation of ulcerative colitis ${ }^{14-16}$ and in the defunctioned colon low concentrations of n-butyrate result in diversion colitis ${ }^{17}$ which is remedied by re-introduction of luminal short chain fatty acids (SCFAs). ${ }^{18}$

Ibuprofen inhibits SCFA oxidation in isolated mitochondria of mouse liver, ${ }^{19}$ an action which in whole animal studies ${ }^{19} 20$ was confirmed to be selective for SCFA and long chain fatty acid oxidation, without affecting glucose oxidation. As NSAIDs may uncouple oxidative phosphorylation in mitochondria and reduce adenosine triphosphate (ATP) production $^{21-24}$ it remained unclear whether the effect of ibuprofen on the colonic mucosa was due to a selective action on fatty acid oxidation or to generalised mitochondrial damage. Because ibuprofen produces colitis ${ }^{125-28}$ independent of bacterial activity ${ }^{29}$ the aim of the present study was to establish the action of ibuprofen on fatty acid and glucose oxidation in isolated colonocytes of healthy rat and man. The effect of ibuprofen was studied with a view to comparing changes observed in healthy colonocytes with those observations made in colonocytes affected by ulcerative colitis. ${ }^{14-16}$

\section{Methods}

TISSUE COLLECTION AND CELL PREPARATION Colonocytes were prepared from female, Sprague-Dawley rats ${ }^{30}$ weighing between 130 and $200 \mathrm{~g}$. Animals were bred in the animal houses of the University of Adelaide, kept on a timed cycle, and used in the fed state, as this produced the optimal yield of cells. Animals were killed by stunning/cervical fracture and the colon was removed and flushed clear of luminal contents with water at $22^{\circ} \mathrm{C}$.

Human colonocytes were prepared from unaffected segments of colon obtained from surgical specimens of patients undergoing colectomy for colorectal cancer. The warm ischaemia time of the colectomy specimens was less than three minutes. The colonic specimen was washed clear of debris with water, cut open, and pinned to assist removal of mucosal strips from the muscularis propria with scissors. Strips were taken at least $10 \mathrm{~cm}$ from tumour tissue.

Isolated colonocytes were prepared and tested for viability as previously described. ${ }^{30}$ Aliquots of $1 \mathrm{ml}$ of cells were used for experimental procedures.

REAGENTS AND PREPARATION

Sodium n-butyrate and D-glucose were obtained from BDH (Melbourne, Australia),
Associate Professor W E W Roediger, Department of Surgery, The Queen Woodville SA 5011 Australia.

Accepted for publication 29 April 1994 


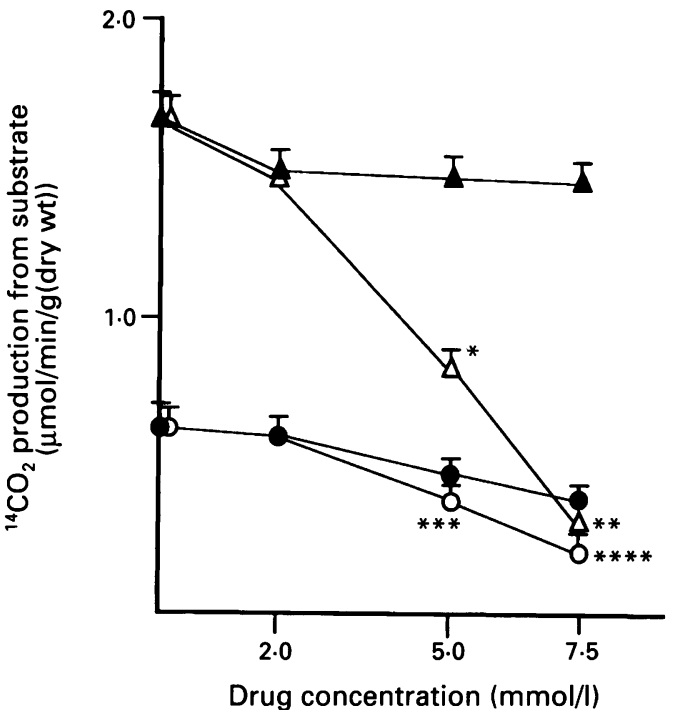

Figure 1: ${ }^{14} \mathrm{CO}_{2}$ production by rat colonocytes from $\left[1-{ }^{14} \mathrm{C}\right]$ butyrate $(\Delta \triangle)$ and $\left[6-{ }^{14} \mathrm{C}\right]$ glucose $(\mathrm{O})$ in the presence of 5-ASA ( $\triangle \mathrm{O})$ or ibuprofen $(\triangle \mathrm{O})$ at doses indicated. The mean (SEM) of seven experiments each comprising cells from four rats are given. Student's paired t test: ${ }^{\star}=p<0.005$ and ${ }^{\star \star}=p<0.001$ compared with control butyrate oxidation; $\star \star \star=p<0.025$ and $\star \star \star \star=p<0.01$ compared with control glucose oxidation.

$\mathrm{n}-\left[1-{ }^{14} \mathrm{C}\right]$ butyrate from DuPont NEN Research (North Sydney, Australia), and $\left[6-{ }^{14} \mathrm{C}\right]$ glucose was purchased from Amersham (Sydney, Australia). Ibuprofen as a $50 \% / 50 \%$ mixture of $S(+)$-ibuprofen and $\mathbf{R}(-)$-ibuprofen was obtained from the Department of Clinical Pharmacology, Queen Elizabeth Hospital, Woodville, Australia, and was originally a gift from the Boots Company PLC (Nottingham, England). Ibuprofen, $2 \cdot 0-7.5 \mathrm{mmol} / \mathrm{l}$, was dissolved in $0.1 \mathrm{M} \mathrm{NaoH}$ followed by addition of $\mathrm{HCl}$ to bring the $\mathrm{pH}$ back to 7.4. Enzymes and co-factors for enzymatic estimation of metabolites were obtained from Boehringer Corporation (North Ryde, Australia) and Sigma Chemical Co (St Louis, MO, USA).

DRUG DOSAGES

Concentrations of 5-aminosalicylic acid (5-ASA) found in the human colon in vivo vary from $12-24 \mathrm{mmol} / 1 .{ }^{31}$ Concentrations used on

TABLE I Acetoacetate and lactate production by isolated rat colonocytes in the presence of glucose or n-butyrate with 5-ASA or ibuprofen. (Values, mean (SEM); number of colons in brackets)

\begin{tabular}{|c|c|c|c|}
\hline \multirow[b]{2}{*}{ Metabolite } & \multirow[b]{2}{*}{ Drug and dose (mmoll) } & \multicolumn{2}{|c|}{ Metabolite formation ( $\mu \mathrm{mol} / \mathrm{min} / \mathrm{g} / \mathrm{dry}$ wt) } \\
\hline & & n-butyrate (5 mmoll) & D-glucose $(5 \mathrm{mmol} / \mathrm{l})$ \\
\hline \multirow[t]{4}{*}{ Acetoacetate } & $\begin{array}{l}\text { Control } \\
\text { Ibuprofen }\end{array}$ & $2 \cdot 72(0 \cdot 29)(6)$ & - \\
\hline & $2 \cdot 0$ & $1.93(0.30)(6)$ & - \\
\hline & $5 \cdot 0$ & $0.61(0.21)(6)^{\star}$ & - \\
\hline & $7 \cdot 5$ & $0.28(0 \cdot 10)(5)^{\star \star}$ & - \\
\hline \multirow[t]{6}{*}{ Lactate } & $\begin{array}{l}\text { Control } \\
\text { Ibuprofen }\end{array}$ & - & $6.33(0.58)(6)$ \\
\hline & $2 \cdot 0$ & - & $6.43(0.68)(6)$ \\
\hline & $5 \cdot 0$ & - & $5.00(0.54)(6)$ \\
\hline & $\begin{array}{c}7 \cdot 5 \\
\text { 5-ASA }\end{array}$ & - & $3.00(0.47)(6)^{\star \star \star}$ \\
\hline & $2 \cdot 0$ & - & $5 \cdot 38(0.43)(6)$ \\
\hline & $\begin{array}{l}5 \cdot 0 \\
7 \cdot 5\end{array}$ & - & $5 \cdot 20(0.13)(6)$ \\
\hline & & & $4.32(0 \cdot 40)(0) \cdot n n$ \\
\hline
\end{tabular}

$\star$ Student's paired $t$ test, $\mathrm{p}<0.01$ compared with control acetoacetate; $\star \star \star \mathrm{p}<0.001$ compared with control acetoacetate; ${ }^{\star \star \star} \mathrm{p}<0.005$ compared with control lactate; ${ }^{\star \star \star \star} \mathrm{p}<0.05$ compared with control lactate. isolated cells were reduced to $2 \cdot 0-7 \cdot 5 \mathrm{mmol} / \mathrm{l}$ as isolated cells are more sensitive to drug dosages than whole organs. The luminal concentrations of ibuprofen that can be attained in the human colon have not been determined and would depend, among other things, on absorption in the small intestine and transit time. A dose comparison was made with 5-ASA even though a $2 \cdot 0-7.5 \mathrm{mmol} / \mathrm{l}$ concentration of ibuprofen may only be achieved at the mucosal level in the upper gastrointestinal tract.

\section{CELL INCUBATIONS}

Cell suspensions, $1 \mathrm{ml}$ representing 5-14 mg dry weight of epithelial cells, were incubated for 40 minutes in conical flasks equipped with a glass centre well and stoppered with Subaseals (William Freeman, UK). The gas phase was $\mathrm{O}_{2}$ and $\mathrm{CO}_{2}(19: 1$, vol/vol). Incubations were performed at $37^{\circ} \mathrm{C}$ in $1 \mathrm{ml}$ of physiological saline containing $2 \%-5 \%$ (wt/vol) bovine serum albumin, dithiothreitol $1 \mathrm{mmol} / \mathrm{l}$, and substrates at $5 \mathrm{mmol} / 1$. The specific activity of $\left[1-{ }^{14} \mathrm{C}\right] \mathrm{n}$-butyrate was 1900 $\mathrm{cpm} / \mu \mathrm{mol}$, and that of $\left[6-{ }^{14} \mathrm{C}\right]$ glucose was $1700 \mathrm{cpm} / \mu \mathrm{mol}$. Ibuprofen, at concentrations of $2 \cdot 0-7.5 \mathrm{mmol} / 1$, was incubated simultaneously with radioactive substrates. The incubation was stopped by adding $0.5 \mathrm{ml}$ of $10 \%$ perchloric acid and the protein precipitate was centrifuged after cooling with ice for two hours. The supernatant was neutralised to pH $7 \cdot 4$ with $20 \%$ potassium hydroxide.

METABOLIC PRODUCT ANALYSIS

Acetoacetate and lactate concentrations were measured enzymatically from neutralised extracts of cells according to Bergmeyer. ${ }^{32}$ The effect of ibuprofen on metabolite analysis was checked and no adverse or synergistic reactions were detected. 5-ASA interfered with the estimation of acetoacetate, which was not therefore measured. Standards of metabolites (lactate, acetoacetate) were included in each assay: the coefficient of variation between standards was less than $1 \% .{ }^{14} \mathrm{CO}_{2}$ were measured as previously described. ${ }^{30}$

\section{CALCULATION AND STATISTICAL ANALYSIS}

Results of metabolic products were expressed per $\mathrm{g}$ dry weight, which was obtained by drying $1 \mathrm{ml}$ of cell suspension to constancy at $90^{\circ} \mathrm{C}$ and corrected for the dry weight of the albumin contained in the medium. ${ }^{14} \mathrm{CO}_{2}$ generation from fatty acid glucose was calculated from the specific activities and trapped ${ }^{14} \mathrm{CO}_{2}$ in $\mathrm{NaOH}$. Observations obtained from the same tissue or animals on which parallel experiments were performed were subject to Student's paired $t$ test. The 0.05 probability level was taken to indicate a significant difference in observations.

\section{Results}

Initial experiments were undertaken with isolated colonocytes from the whole colon of 


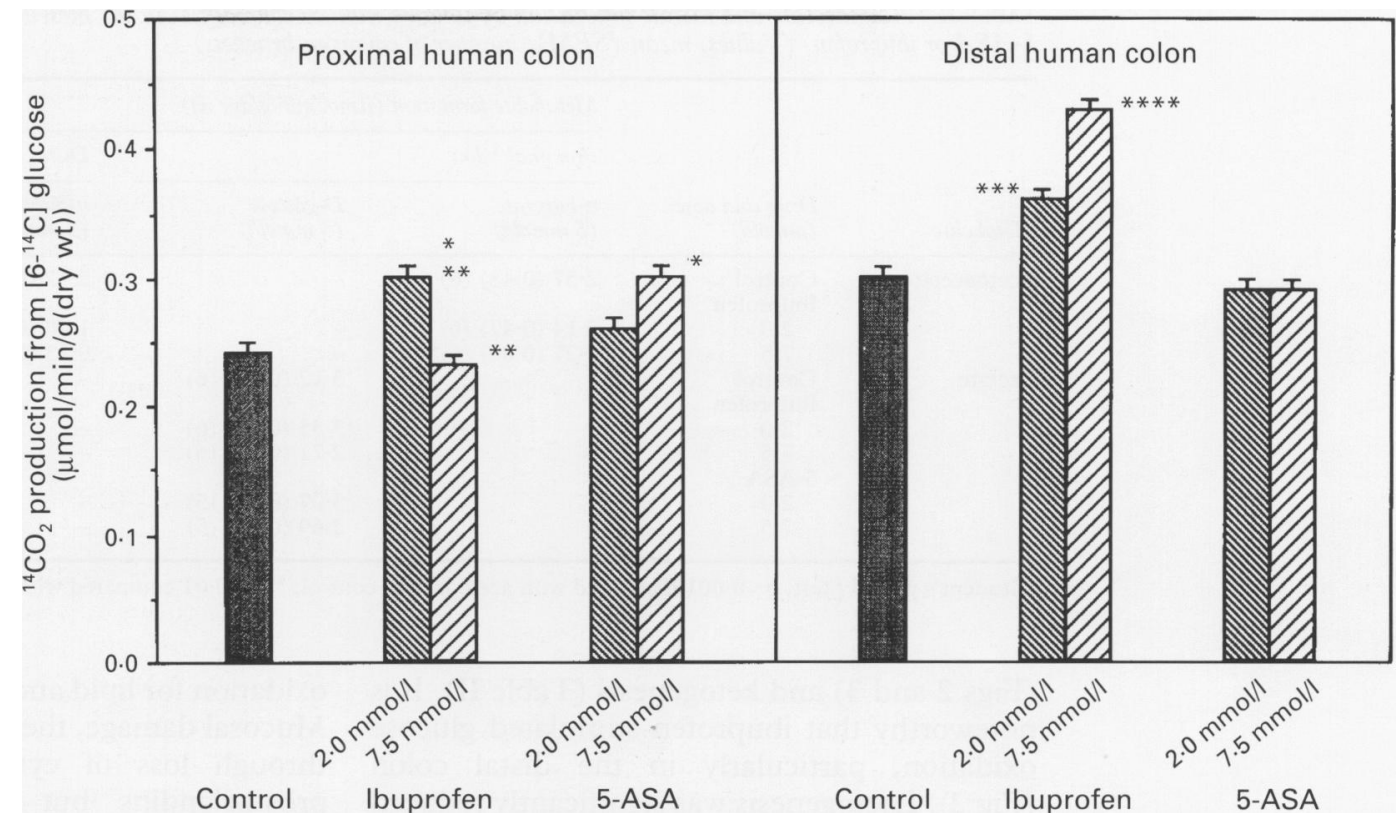

Figure $2:{ }^{14} \mathrm{CO}_{2}$ production by human colonocytes from $\left[6-{ }^{14} \mathrm{C}\right]$ glucose in the presence of 2.0 and $7.5 \mathrm{mmol}$ of $5-\mathrm{ASA}$ and ibuprofen in the proximal and distal human colons. Observations are mean (SEM) of six colons at each site, with parallel experiments from the same batch of cells. Student's paired $\mathrm{t}$ test: ${ }^{\star}=p<0.05$ compared with control; ${ }^{\star \star}=p<0.05$, 2.0 mmoll ibuprofen compared with 7.5 mmoll ibuprofen; ${ }^{\star \star \star}=p<0.025$ and ${ }^{\star \star \star \star}=p<0.01$ compared with control.

the rat to establish effects of dosage changes with ibuprofen and 5-ASA. Ibuprofen dose dependently decreased both n-butyrate and D-glucose oxidation to $\mathrm{CO}_{2}$. Reduction of ${ }^{14} \mathrm{CO}_{2}$ production from $1.68(0.12)$ to 0.36 $(0 \cdot 11) \mu \mathrm{mol} / \mathrm{min} / \mathrm{g}$ (dry weight) with $\left[1-{ }^{14} \mathrm{C}\right]$ n-butyrate occurred at the $7.5 \mathrm{mmol} / \mathrm{l}$ concentration of ibuprofen (Fig 1), which reflected a $79 \%$ reduction of fatty acid oxidation, while reduction of glucose at that concentration of drug was $60 \%$ from $0.60(0.04)$ to 0.24 $(0.06) \mu \mathrm{mol} / \mathrm{min} / \mathrm{g}$ (dry weight). Ketogenesis and lactogenesis were reduced in parallel with the reduction of ${ }^{14} \mathrm{CO}_{2}$ (Table I). 5-ASA led to a slight reduction in both butyrate and glucose oxidation, a reduction that at $7.5 \mathrm{mmol} / \mathrm{l}$ was significantly different from that produced by ibuprofen $(p=<0.01$ for glucose and $\mathrm{p}=<0.001$ for $\mathrm{n}$-butyrate).

Human colonocytes were only exposed to drug concentrations of 2.00 and $7.5 \mathrm{mmol} / 1$ with both glucose and n-butyrate, each drug exposure comprising cells from the same batch of cell isolates. Unlike findings with rat colonocytes, 5-ASA did not reduce either n-butyrate or glucose oxidation in the proximal or distal human colon, but ibuprofen at $7.5 \mathrm{mmol} / \mathrm{l}$ selectively diminished fatty acid oxidation

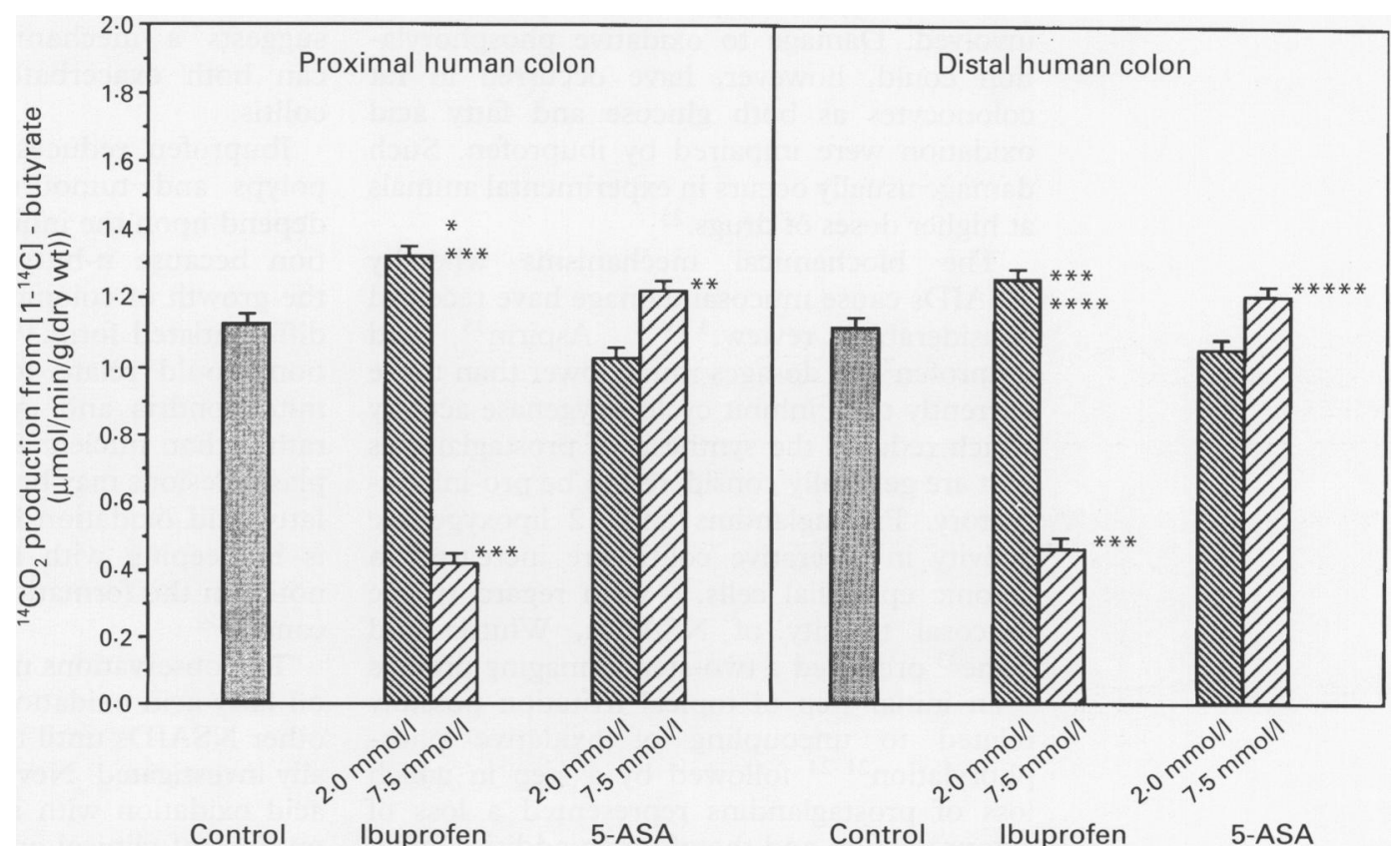

Figure 3: ${ }^{14} \mathrm{CO}_{2}$ production by human colonocytes from $\left[1{ }^{14} \mathrm{C}\right]$ n-butyrate in the presence of $2 \cdot 0$ and $7 \cdot 5 \mathrm{mmol} / \mathrm{of}$ 5-ASA and ibuprofen in the proximal and distal human colon. Observations are mean (SEM) of six colons at each site with parallel experiments from the same batch of cells. Student's paired $t$ test: $\star=p<0 \cdot 01$ and $\star \star=N S$ compared with

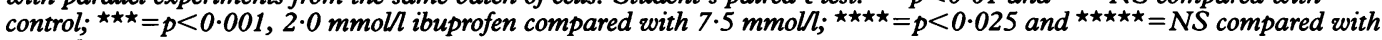
control. 
TABLE II Acetoacetate and lactate production by isolated human colonocytes in the presence of glucose or n-butyrate with 5-ASA or ibuprofen. (Values, mean (SEM); number of colons in brackets)

\begin{tabular}{|c|c|c|c|c|c|}
\hline \multirow[b]{3}{*}{ Metabolite } & \multirow[b]{3}{*}{$\begin{array}{l}\text { Drug and dose } \\
\text { (mmoll) }\end{array}$} & \multicolumn{4}{|c|}{ Metabolite formation ( $\mu \mathrm{mol} / \mathrm{min} / \mathrm{g} / \mathrm{dry} w \mathrm{w})$} \\
\hline & & \multicolumn{2}{|l|}{ Proximal colon } & \multicolumn{2}{|l|}{ Distal colon } \\
\hline & & $\begin{array}{l}n \text {-butyrate } \\
(5 \text { mmoll })\end{array}$ & $\begin{array}{l}\text { D-glucose } \\
(5 \mathrm{mmol} / \mathrm{l})\end{array}$ & $\begin{array}{l}n \text {-butyrate } \\
(5 \text { mmoln) }\end{array}$ & $\begin{array}{l}\text { D-glucose } \\
(5 \mathrm{mmol})\end{array}$ \\
\hline \multirow[t]{2}{*}{ Acetoacetate } & Control & $2 \cdot 57(0.48)(6)$ & - & $2 \cdot 17(0.53)(5)$ & - \\
\hline & $\begin{array}{l}2 \cdot 0 \\
7 \cdot 5\end{array}$ & $\begin{array}{l}2.14(0.47)(6) \\
0.27(0.08)(6)^{\star}\end{array}$ & $\begin{array}{l}- \\
-\end{array}$ & $\begin{array}{l}1.40(0.22)(5) \\
0.13(0.03)(5)^{\star}\end{array}$ & $\begin{array}{l}- \\
-\end{array}$ \\
\hline \multirow[t]{3}{*}{ Lactate } & $\begin{array}{l}\text { Control } \\
\text { Ibuprofen }\end{array}$ & - & $3 \cdot 12(0.55)(6)$ & - & $3.54(0.21)(6)$ \\
\hline & $\begin{array}{c}2 \cdot 0 \\
7 \cdot 5 \\
5-\mathrm{ASA}\end{array}$ & - & $\begin{array}{l}3.35(0.58)(6) \\
2.71(0.51)(6)\end{array}$ & $\begin{array}{l}- \\
-\end{array}$ & $\begin{array}{l}3.70(0.3)(6) \\
2.62(0.24)(6)^{\star \star}\end{array}$ \\
\hline & $\begin{array}{l}2 \cdot 0 \\
7 \cdot 5\end{array}$ & - & $\begin{array}{l}3.07(0.67)(5) \\
2.69(0.41)(5)\end{array}$ & - & $\begin{array}{l}3.39(0.27)(6) \\
2.80(0.23)(6)^{\star \star}\end{array}$ \\
\hline
\end{tabular}

${ }^{\star}$ Student's paired $t$ test, $\mathrm{p}<0.001$ compared with acetoacetate control; ${ }^{\star \star} \mathrm{p}<0.01$ compared with lactate control.

(Figs 2 and 3) and ketogenesis (Table II). It is noteworthy that ibuprofen stimulated glucose oxidation, particularly in the distal colon (Fig 2). Lactogenesis was significantly reduced in the presence of 5-ASA (Table II), a feature that was not parallelled by a reduction of ${ }^{14} \mathrm{CO}_{2}$ from the respective substrates.

\section{Discussion}

The detrimental change in fatty acid but not glucose oxidation induced by ibuprofen in human colonocytes suggests maintenance of the Krebs cycle and therefore mitochondrial function in cells. 5-ASA did not change fatty acid oxidation of colonocytes in line with observations made by Ireland and Jewell. ${ }^{15}$ The effect of ibuprofen on fatty acid oxidation in human colonocytes was analogous to that observed by Freneaux et al ${ }^{19}$ with isolated liver mitochondria and in intact animals. As both ketone body and $\mathrm{CO}_{2}$ production were equally reduced in colonocytes, a change within the $\beta$-oxidation pathway rather than the Lynen (ketone body) pathway or Krebs cycle must be involved. Damage to oxidative phosphorylation could, however, have occurred in rat colonocytes as both glucose and fatty acid oxidation were impaired by ibuprofen. Such damage usually occurs in experimental animals at higher doses of drugs. ${ }^{23}$

The biochemical mechanisms whereby NSAIDs cause mucosal damage have received considerable review. ${ }^{3334}$ Aspirin $^{35}$ and ibuprofen $^{36}$ at dosages much lower than those currently used inhibit cyclo-oxygenase activity which reduces the synthesis of prostaglandins that are generally considered to be pro-inflammatory. Prostaglandins and 12 lipoxygenase activity in ulcerative colitis are increased in colonic epithelial cells. ${ }^{37}$ With regard to the mucosal toxicity of NSAIDs, Whittle and Vane $^{33}$ proposed a two-step damaging process - an initial step of topical irritation possibly related to uncoupling of oxidative phosphorylation ${ }^{21-24}$ followed by a step in which loss of prostaglandins represented a loss of cytoprotection and therefore an additive effect to mucosal damage. Present observations with fatty acid oxidation in human colonocytes indicate that very high dosages of ibuprofen limit the supply of acetyl-CoA from fatty acid oxidation for lipid and prostaglandin synthesis. Mucosal damage, therefore, may not always be through loss of cytoprotection of reduced prostaglandins but perhaps via metabolic damage through changes in fatty acid oxidation. A precise relationship between drug dosages, mucosal injury, impaired fatty acid oxidation, and reduced mucosal prostaglandin synthesis in colonocytes needs to be established by further experimentation as was done in gastric mucosal injuries. ${ }^{38}$

The reduction of butyrate oxidation by $79 \%$ by ibuprofen in human colonocytes reflects an overall decrease of $55 \%$ of cell energy as butyrate normally supplies $70 \%$ of cellular oxidation ${ }^{9-11}$ in colonocytes. Because both lipogenesis ${ }^{12}$ and efficient absorption are dependent upon butyrate-oxidation, any impairment of fatty acid oxidation can explain changes of membrane permeability ${ }^{4}$ observed with ibuprofen. The mechanism proposed for ibuprofen damage in the colon is in line with the evolution of ulcerative colitis that is related to impairment of fatty acid oxidation. ${ }^{14-16} \mathrm{~A}$ reduction in fatty acid oxidation suggests a mechanism whereby ibuprofen can both exacerbate and cause ulcerative colitis.

Ibuprofen reduces the growth of colonic polyps and tumours. ${ }^{39} 40$ This effect may depend upon the inhibition of butyrate oxidation because n-butyrate normally promotes the growth of colonic tumour cells to a more differentiated form. ${ }^{41}$ The proposed explanation would relate to metabolic changes in mitochondria and cytoplasm of colonocytes rather than nucleic acids, implying that neoplastic lesions may be diminished by change in fatty acid oxidation but not eradicated. This is in keeping with the effects of ibuprofen noted in the formation of experimental colon cancer. ${ }^{39}$

The observations now made with ibuprofen on fatty acid oxidation cannot be extended to other NSAIDs until these have been individually investigated. Nevertheless changes in fatty acid oxidation with ibuprofen may explain a number of clinical and experimental observations with regard to colonic mucosal disease, especially ulcerative colitis. The dose dependent metabolic changes observed in the colonocytes indicate that continued use of 
ibuprofen is possible in colonic disease but at a lower dosage range.

With sincere thanks to Mrs E Mazel and Mrs S Ireland for word processing the manuscript.

1 Rampton DS, Sladen GE. Relapse of ulcerative proctocolitis during treatment with non-steroidal anti-inflammatory drugs. Postgrad Med F 1981; 57: 297-99.

2 Gibson GR, Whitacre EB, Ricotti CA. Colitis induced by non-steroidal anti-inflammatory drugs. Arch Intern Med 1992; 152: 625-32.

3 Bjarnason I, Hayllar J, Macpherson AJ, Russell AS. Side effects of non-steroidal anti-inflammatory drugs on the small and large intestine in humans. Gastroenterology 1993; 104: 1832-47.

4 Jenkins AP, Trew DR, Crump BJ, Nukajam WS, Foley JA, Menzies IS, et al. Do non-steroidal anti-inflammatory Menzies IS, et al. Do non-steroidal anti-inflammatory

drugs increase colonic permeability? Gut 1991; 32: 66-9.
5 Holt S, Rigoglioso V, Sidhu M, Irshad M, Howden CW, Maneiro M. Nonsteroidal anti-inflammatory drugs and lower gastrointestinal bleeding. Dig Dis Sci 1993; 38 1619-23.

6 Huber T, Ruchti C, Halter F. Nonsteroidal anti-inflammatory drug-induced colonic strictures: a case report. Gastroenterology 1991; 100: 1119-22.

7 Halter F, Weber B, Huber T, Eigenmann F, Frey MP, Ruchti C. Diaphragm disease of the ascending colon. Association with sustained release diclofenac. $\mathcal{f}$ Clin Gastroenterol 1993; 16: 74-80.

8 Whittle BJR. Temporal relationship between cyclooxygenase inhibition as measured by prostacyclin biosynthesis and gastrointestinal damage induced by indomethacin in the rat. Gastroenterology 1981; 80: 94-8.

9 Roediger WEW. The role of anaerobic bacteria in the metabolic welfare of the colonic mucosa in man. Gut 1980; 21 793-8.

10 Ardawi MSM, Newsholme EA. Fuel utilization in colonocytes of the rat. Biochem $71985 ; 231: 713-9$.

11 Fleming SE, Fitch MD, Devries S, Liu ML, Kight C. Nutrient utilization by cells isolated from rat jejunum, cecum and colon. $\mathbf{f}$ Nutr 1991; 121: 869-78.

12 Roediger WEW, Kapaniris O, Millard S. Lipogenesis from n-butyrate in colonocytes. Action of reducing agent and 5-aminosalicylic acid with relevance
Moll Cell Biochem 1992; 118: 113-8.

13 Ramakrishna BS, Roberts-Thomson IC, Pannall PR Roediger WEW. Impaired sulphation of phenol by the colonic mucosa in quiescent and active ulcerative colitis. Gut 1991; 32: 46-9.

14 Roediger WEW. The colonic epithelium in ulcerative colitis - an energy deficiency disease? Lancet 1980; ii: 712-5.

15 Ireland A, Jewell DP. 5-aminosalicylic acid (5-ASA) has no effect on butyrate metabolism in human colonic epithelial cells. Gastroenterology 1990; 98: A176.

16 Chapman MAS, Grahn ME, Hutton M, Rogers J, Williams NS. Failure of colonic mucosa to oxidise butyrate in NS. Failure of colonic mucosa to oxidise but
ulcerative colitis. Gut 1991; 33: 540 (abstract).

17 Glotzer DJ, Glick ME, Goldman H. Proctitis and colitis following diversion of the fecal stream. Gastroenterology 1981; 80: 438-41.

18 Harig JM, Soergel KH, Komorowski RA, Wood CM Treatment of diversion colitis with short-chain-fatty acid irrigation. New Engl f Med 1989; 320: 23-8.

19 Freneaux E, Fromenty B, Berson A, Labbe G, DeGott C, Letteron $\mathrm{P}$, et al. Stereoselective and non-stereoselective effects of ibuprofen enantiomers on mitochondrial $\beta$-oxidation of fatty acids. $\mathcal{J}$ Pharmacol Exp Therap 1990; 255: 529-35.

20 Zhao B, Geisslinger G, Hall I, Day RO, Williams KM. The effect of the enantiomers of ibuprofen and flurbiprofen on the $\beta$-oxidation of palmitate in the rat. Chirality 1991; 4: $137-41$.
21 Glanborg-Jorgensen T, Weis-Fough US, Nielsen $\mathbf{H H}$, Olsen HP. Salicylate and aspirin-induced uncoupling of oxidative phosphorylation in mitochondria isolated from the mucosal membrane of the stomach. Scan $\mathcal{F}$ Clin Invest 1976; 36: 649-53.

22 Spenney JG, Bhown $M$. Effect of acetylsalicylic acid on gastric mucosa. II Mucosal ATP and phosphocreatine content and salicylic effects on mitochondrial metabolism. Gastroenterology 1977; 73: 995-9.

23 Ohe K, Hayashi K, Shirakawa T, Yamada K, Kawasaki T Miyoshi A. Aspirin - and taurocholate-induced metabolic damage in mammalian gastric mucosa in vitro. Am f Physiol 1982; 239: 624-35.

24 Somasundaram S, Machperson AJ, Hayllar J, Saratchandra P, Bjarnason I. Enterocyte mitochondrial damage due to NSAID in the rat. Gut 1992; 33 (suppl): S5.

25 Schwartz HA. Lower gastrointestinal side effects of nonsteroidal anti-inflammatory drugs. $\mathcal{F}$ Rheumatol $1981 ; 8$ : 952-4.

26 Walt RP, Hawkey CJ, Langman MJS. Colitis associated with non-steroidal anti-inflammatory drugs. BMF 1984; 288: 238 .

27 Charuzi I, Ovnat A, Zirkin H, Peiser J, Sukenik S Ibuprofen and benign cecal ulcer. $\mathcal{F}$ Rheumatol 1985; 12: 188-9.

28 Ravi S, Keat AC, Keat ECB. Colitis caused by nonsteroidal anti-inflammatory drugs. Postgrad Med $\mathcal{F}$ 1986; 62: 773-6.

29 Melarange R, Moore G, Blower PR, Coates ME, Ward FW, Ronaasen V. A comparison of indomethacin with ibuprofen on gastrointestinal mucosal integrity in conventional and germ-free rats. Aliment Pharmacol Ther 1992; 6: 67-77.

30 Roediger WEW, Truelove SC. Method of preparing isolated colonic epithelial cells (colonocytes) for metabolic tudies. Gut 1979; 20: 484-8

31 Staerk Laursen L, Stokholm M, Bukhave K, Rask-Madsen $\mathrm{J}$, Lauritsen K. Disposition of 5-aminosalicylic acid by olsalazine and three mesalazine preparations in patients with ulcerative colitis: comparison of intra-luminal colonic concentrations, serum values and urinary excretion. Gut 1990; 31: 1271-6.

32 Bergmeyer HU, Bergmeyer J, Grass M. Methods of enzymatic analysis. 3rd ed. Weinheim: Verlag Chemie 1984, vol VI, 582-8, vol VIII, 61-9.

33 Whittle BJR, Vane JR. A biochemical basis for the gastrointestinal toxicity of non-steroid antirheumatoid drugs. intestinal toxicity of non-steroid an

34 Williams KM, Day RO, Breit SN. Biochemical actions and clinical pharmacology of anti-inflammatory drugs. Adv Drug Res 1993; 24: 121-98.

35 Vane JR. Inhibition of prostaglandin synthesis as a mechanism of action of aspirin-like drugs. Nature (New Biol) $1971 ; 231: 232-35$.

36 Rome LH, Lands WEM. Structural requirements for timedependent inhibition of prostaglandin biosynthesis by anti-inflammatory drugs. Proc Nat Acad Sci USA 1975; 75: 4863-5.

37 Shannon VR, Stenson WF, Holtzmann NJ. Induction of epithelial arachidonate 12-lipoxygenase at active sites of inflammatory bowel disease. Am $\mathcal{f}$ Physiol 1993; 264: inflammat

38 Levine RA, Petokas S, Nandi J, Enthoven D. Effects of nonsteroidal anti-inflammatory drugs on gastrointestinal njury and prostanoid generation in healthy volunteers. Dig Dis Sci 1988; 33: 660-6.

39 Reddy BS, Tokumo K, Kulkarni N, Aligia C, Keloff G. Inhibition of colon carcinogenesis by prostaglandin synthesis inhibitors and related compounds. Carcinogenesis 1992; 13: 1019-23.

40 Boone CW, Steele VE, Kelloff GJ. Screening for chemopreventative (anticarcinogenic) compounds in rodents. preventative (anticarcinogenic)

41 Whitehead RH, Young GP, Bhathal PS. Effect of short chain fatty acids on a new human colon carcinoma cell line (LIM 1215). Gut 1986; 27: 1457-61. 